\title{
Nasal peripheral primitive neuroectodermal tumor in a heifer: case report
}

\section{Tumor neuroectodérmico primitivo periférico na cavidade nasal em uma novilha: relato de caso}

\author{
Fernando Froner Argenta ${ }^{1 *}$; Márcia Elisa Hammerschmitt ${ }^{1}$; Matheus de Oliveira \\ Reis $^{2}$; Raquel Aparecida Sales da Cruz ${ }^{3}$; Cíntia De Lorenzo ${ }^{1}$; Luciana Sonne ${ }^{4}$; \\ David Driemeier'; Saulo Petinatti Pavarini ${ }^{4}$
}

\begin{abstract}
This report described the clinical signs, pathological and immunohistochemical findings associated with a peripheral primitive neuroectodermal tumor (pPNET) in the nasal cavity of a heifer. The heifer exhibited severe breathing difficulty and dysphagia, which were increased over the last thirty days. At autopsy, a large, firm, and whitish mass was found occupying the left frontal sinus and most of the left nasal cavity. Histologically, a malignant neoplastic proliferation was observed, which was composed of small cells typically arranged in nests and mantles, occasionally arranged in palisade, interspersed with moderate connective stroma. The neoplastic cells exhibited strong immunoreactivity to synaptophysin, mild, multifocal immunoreactivity to neuron-specific enolase and vimentin, with moderate, and multifocal immunoreactivity S-100 protein. These findings suggest that pPNETs should be included in the differential diagnosis of proliferative and obstructive lesions in the nasal cavity of young cattle. Key words: Neoplasm. Immunohistochemistry. PNET.
\end{abstract}

\section{Resumo}

\begin{abstract}
Este relato descreve os sinais clínicos, achados patológicos e imuno-histoquímicos associados a um tumor neuroectodérmico primitivo periférico (pPNET) na cavidade nasal de uma novilha. A novilha apresentava dificuldade respiratória e de deglutição, com evolução de trinta dias. Na autópsia, no seio frontal esquerdo e ocupando quase toda a cavidade nasal esquerda foi observada uma grande massa firme e esbranquiçada. Histologicamente, observou-se proliferação neoplásica maligna composta de pequenas células dispostas em ninhos e manto, ocasionalmente em paliçada, intercaladas por estroma conjuntivo moderado. As células neoplásicas exibiram intensa imunomarcação para sinaptofisina, marcação leve e multifocal para enolase neurônio especifica e vimentina, com multifocal e moderada imunorreação para a proteína S-100. Esses achados sugerem que o pPNET deve ser incluído no diagnóstico diferencial de lesões proliferativas e obstrutivas na cavidade nasal de bovinos jovens.
\end{abstract}

Palavras-chave: Neoplasma. Imuno-histoquímica. PNET.

\footnotetext{
1 Discentes de Doutorado em Ciências Veterinárias, Universidade Federal do Rio Grande do Sul, UFRGS, Porto Alegre, RS, Brasil.E-mail: nando.arg83@gmail.com; marciahammer@hotmail.com; cintiadelorenzobr@gmail.com

2 Discente de Doutorado em Ciência Animal, Universidade Federal de Lavras, UFLA, Lavras, MG, Brasil. E-mail: matheus_ reis91@hotmail.com

3 Prof ${ }^{\mathrm{a}}$ Dra , Universidade de Cuiabá, UNIC, Cuiabá, MT, Brasil. E-mail: raquel.asc@hotmail.com

4 Profs. Drs., UFRGS, Porto Alegre, RS, Brasil. E-mail: lusonne@yahoo.com.br; davetpat@ufrgs.br; sauloppvet@yahoo.com.br

* Author for correspondence
} 


\section{Introduction}

Primitive neuroectodermal tumors (PNETs) are embryonal malignant neoplasms that are composed of primitive neuroepithelial cells. They are classified as cerebellar (known as medulloblastoma) and extracerebellar. The extracerebellar tumors are further divided into central (cPNET) and peripheral (pPNET) types (KOESTNER et al., 1999). In humans, PNETs consist of neoplasms of the Ewing's sarcoma family (WINDFUHR et al., 2004). In cattle, PNETs have been described in the brain (LUCAS et al., 2003), spinal cord (BERROCAL et al., 2005), and nasopharynx (UCHIDA et al., 1998). This report describes the clinical signs, and pathological, and immunohistochemical (IHC) findings associated with a case of pPNET observed in the nasal cavity of a heifer.

\section{Case Report}

A female bovine mixed-breed, of two years and four months of age, who had a history of breathing difficulty and severe dysphagia, which increased over the last thirty days. During the physical examination, the heifer exhibited poor body condition, aggressiveness, and severe breathing difficulty combined with estertor. Further, sialorrhea, lateral deviation of the head, as well as protrusion of the left eye with corneal ulceration and severe ocular purulent secretion were observed (Figure 1A). The euthanasia was done due to poor prognosis.

At autopsy, a mass measuring $20 \times 15 \times 15 \mathrm{~cm}$ occupying a portion of the left frontal sinus and most of the left nasal cavity was observed. The mass was relatively delimited, unencapsulated, multilobulated, firm, and whitish, with multifocal areas of friable and yellowed intratumoral necrosis. The presence of the mass dislocated the nasal septum to the right, and the involvement of the optic nerve resulted in protrusion of the left eye. A sagittal section through the head revealed that the mass extended dorsally of the cribriform plate of the ethmoid bone to the initial portion of the nasal turbinate and obstructed the oropharynx ventrally (Figure 1B). Additionally, large amounts of yellow mucus were found associated with the mass and inside the sinuses. No gross alterations were observed in other tissues.

Fragments of the neoplasm of the nasal cavitywere collected and fixed in buffered $10 \%$ formalin solution and then processed for routine histopathology. The samples were stained using the hematoxylin and eosin (HE) technique. Immunohistochemistry (IHC) of sections of the mass was performed by using the Streptavidin-biotin-peroxidase complex method for all antibodies, except for the antiCD79acy antibody (peroxidase polymer $[\mathrm{MACH}$ 4]). Positive controls consisted of bovine pancreas (synaptophysin), canine skin (cytokeratin), canine adrenal [(chromogranin A and neuron specific enolase (NSE)], swine tonsils (CD79acy and CD3), bovine brain [glial fibrillary acidic protein (GFAP) and bovine neurofilament] and canine peripheral nerve sheath tumor (vimentin and S-100 protein). For negative control, phosphate buffered saline substituted the primary antibodies in each IHC assay. The chromogen used for the revelation was 3,3-diamino-benzidine tetrahydrochloride (DAB) and 3-amino-9-ethylcarbazole (AEC), and counterstained the samples using either Harris's or Mayer's hematoxylin. Table 1 shows the antibodies and protocols utilized in this analysis.

Histologic examination revealed an unencapsulated malignant neoplastic proliferation, which was composed of small cells typically arranged in nests and mantles, occasionally arranged in palisade, interspersed with moderate connective stroma (Figure 1C). Cellular morphology varied from rounded to columnar, and occasionally included elongation (cells in a carrot shape); indistinct cytoplasmic margins, sparse and slightly eosinophilic cytoplasm, as well as nuclei with a rounded, oval or cuboidal shape, containing either 
dense chromatin and a coarsely granular, unique, and evident nucleolus were also observed (Figure 1D). There was moderate cellular and nuclear pleomorphism, and an average of two mitotic figures upon high-powered magnification (400x) was observed. Furthermore, the neoplasm infiltrated into adjacent bone tissue, with multiple regions of necrosis that were associated with moderate and multifocal hemorrhage, and a discrete lymphocytic inflammatory infiltrate.

Table 1. Antibodies and immunohistochemical protocols used in this case report.

\begin{tabular}{|c|c|c|c|}
\hline Antibody & Code & Dilution & Antigenic Recovery \\
\hline Mouse anti-vimentin ${ }^{\mathrm{a}}$ & 1411602 & $1: 200$ & Citrate buffer pH 6.0 pressure cooker $125^{\circ} \mathrm{C}, 3^{\prime}$ \\
\hline Mouse anti-cytokeratin ${ }^{\mathrm{b}}$ & M3515 & $1: 80$ & Citrate buffer $\mathrm{pH} 6.0$ pressure cooker $125^{\circ} \mathrm{C}, 3^{\prime}$ \\
\hline CD79 $\alpha c y^{b}$ & M7051 & $1: 100$ & Tris EDTA pH 9.0 pressure cooker $96^{\circ} \mathrm{C}, 20^{\prime}$ \\
\hline Mouse anti-neuron specific enolase ${ }^{b}$ & M0873 & $1: 200$ & Citrate buffer pH 6.0 pressure cooker $96^{\circ} \mathrm{C}, 40^{\prime}$ \\
\hline Anti-synaptophysinc ${ }^{\mathrm{C}}$ & ab8049 & $1: 50$ & Tris EDTA pH 9.0 pressure cooker $96^{\circ} \mathrm{C}, 20^{\prime}$ \\
\hline Rabbit anti-CD3 ${ }^{b}$ & A0452 & $1: 500$ & Protease XIV 15, \\
\hline Rabbit anti-glial fibrillary acidic protein ${ }^{\mathrm{b}}$ & Z0334 & $1: 500$ & Tris EDTA pH 9.0 pressure cooker $100^{\circ} \mathrm{C}, 10^{\prime}$ \\
\hline Rabbit anti-S-100 & Z0311 & $1: 200$ & Citrate buffer pH 6.0 pressure cooker $96^{\circ} \mathrm{C}, 20^{\prime}$ \\
\hline Rabbit anti-chromogranin $\mathrm{A}^{\mathrm{b}}$ & A0430 & $1: 200$ & Citrate buffer $\mathrm{pH} 6.0$ pressure cooker $96^{\circ} \mathrm{C}, 20^{\prime}$ \\
\hline $\begin{array}{l}\text { Rabbit anti-bovine Neurofilament } \\
\mathrm{H} 200 \mathrm{KDa}^{\mathrm{d}}\end{array}$ & AHP245 & $1: 500$ & $\begin{array}{c}\text { Trypsin } 0,1 \% 37^{\circ} \mathrm{C} \text {, citrate buffer } \mathrm{pH} 6.02^{\prime} \\
\text { microwave }\end{array}$ \\
\hline
\end{tabular}

Acquisition sources: ${ }^{\mathrm{a} Z y m e d,}{ }^{\mathrm{b}} \mathrm{Dako},{ }^{\mathrm{c}} \mathrm{Abcam}$ and ${ }^{\mathrm{d}}$ Serotec.

IHC analysis showed an intense multifocal immunoreactivity for synaptophysin (Figure 1E), mild for the presence of both NSE and vimentin, and a moderate immunoreactivity for $\mathrm{S}-100$ protein within the cytoplasm of neoplastic cells (Figure $1 F)$. Immunoreactivity to the neoplastic cells was not found when antibodies specific for cytokeratin, CD3, CD79acy, GFAP, neurofilament protein and chromogranin A were used.

The clinical observations in this heifer are similar to previous reports in cattle, and were characterized by exophthalmos, epistaxis, facial deformities, neurological signs and breathing difficulty
(UCHIDA et al., 1998; LUCAS et al., 2003). The exophthalmos, ataxia, and neurological signs were described in a Japanese black bull where a pPNET in the nasopharyngeal region had infiltrated the cerebral cortex (UCHIDA et al., 1998).

In humans, pPNET may develop at any age, but is most common in patients under 20 years of age (WINDFUHR, 2004). The age of the heifer in this case, as well as in the cases described in other studies (UCHIDA et al., 1998; LUCAS et al., 2003; BERROCAL et al., 2005), suggests a predilection to occur in young cattle. 
Figure 1. A. Bovine with poor body condition, sialorrhea and protrusion of the left eye with corneal ulceration. B. A sagittal slice of the head exhibiting a firm, whitish, multilobular mass in the nasal cavity. Bar, $3 \mathrm{~cm}$. C. Neoplastic proliferation constituted by small cells arranged in nests and mantles, interspersed with moderate connective stroma, with multiple areas of necrosis. HE. Bar, $200 \mu \mathrm{m}$. D. Neoplastic cells with nucleos elongated in a carrot shape. HE. Bar, $50 \mu \mathrm{m}$. E. The cytoplasm of neoplastic cells shows strong synaptophysin immunoreactivity. IHC, DAB. Bar, 50 $\mu \mathrm{m}$. F. Moderate S-100 protein immunoreactivity in the cytoplasm and nucleus of neoplastic cells. IHC, AEC. Bar, $50 \mu \mathrm{m}$.

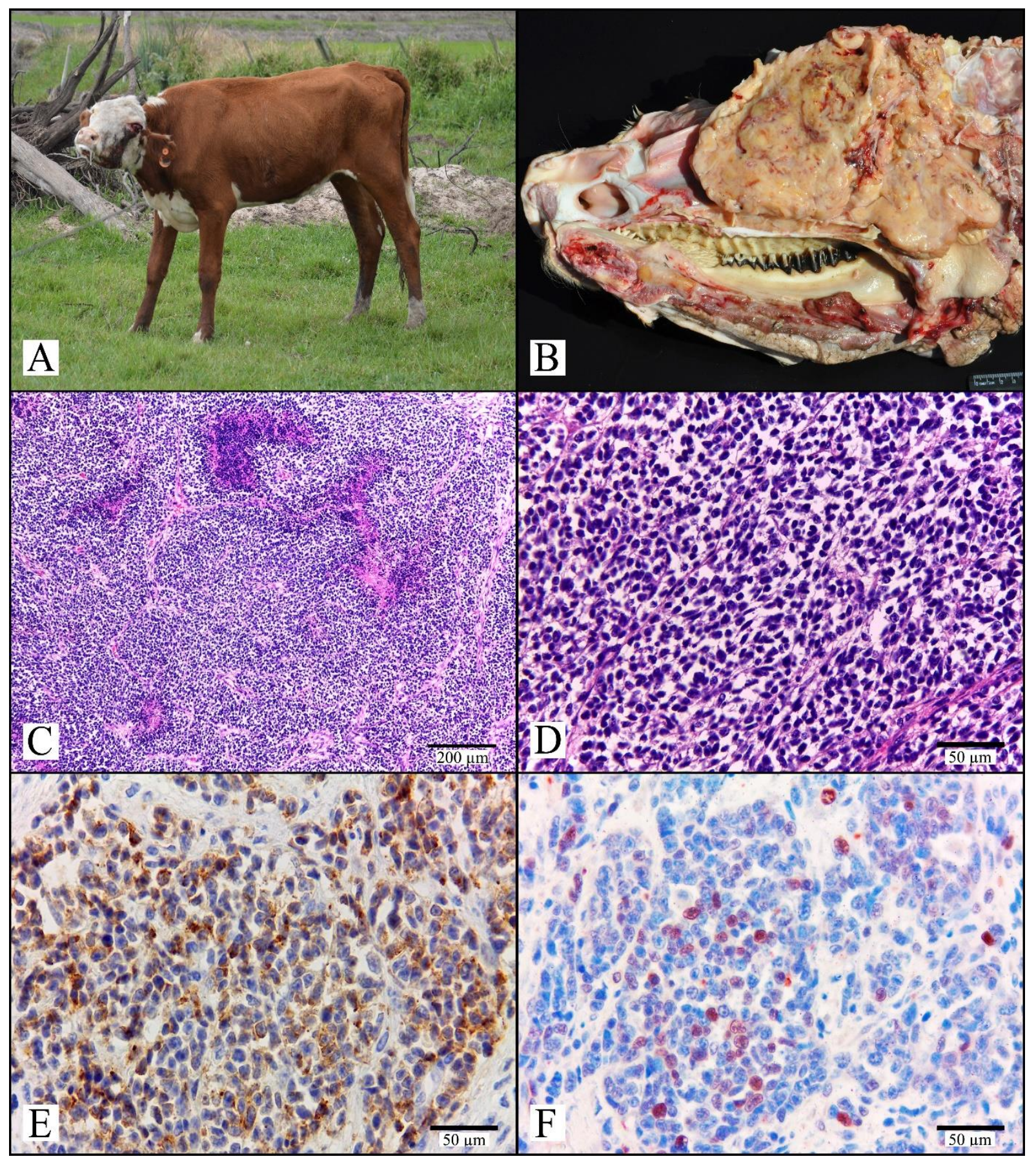


The gross aspects of the pPNET in this case were similar to those observed in dogs (KATAYAMA et al., 2001) and other cases in cattle (UCHIDA et al., 1998; LUCAS et al., 2003), and were characterized by a relatively delimited, white-to-gray tumor, where the sectioned surface had multiple foci of necrosis and hemorrhage (UCHIDA et al., 1998; KATAYAMA et al., 2001). Histopathologic findings are similar to prior reports (UCHIDA et al., 1998; KOESTNER et al., 1999; BERROCAL et al., 2005), which have described a proliferation of round cells with numerous elongated cells in a carrot shape, arranged in nests or cords. A palisade distribution pattern is common; occasionally, neoplastic cells were arranged in structures similar to Home-Wright and Flexner-Wintersteiner rosettes. Frequent mitoses, intratumoral necrosis, and hemorrhage are also common findings (UCHIDA et al., 1998; KOESTNER et al., 1999; BERROCAL et al., 2005). The origin and type of this tumor were determined by immunohistochemical evaluation, which indicated that the cells originate from the neuroectodermal tissue within the nasal cavity (WILSON; DUNGWORTH, 2002). The moderateto-strong immunoreactivity for synaptophysin, NSE and S-100 protein, combined with the absence of immunoreactivity for cytokeratin, confirms our diagnosis of neuroectodermal neoplasm in this case. According to Wilson and Dungworth (2002), a precise and definitive immunohistochemical diagnosis is difficult because of a high variation in the expression of glial markers in neuroendocrine and neuroectodermal neoplasms of the nasal cavity. Several authors have observed immunohistochemical expression for NSE, S-100, synaptophysin, and vimentin proteins in a similar pattern observed in the present case (LUCAS et al., 2003; BERROCAL et al., 2005).

Other neoplasms may form in the nasal cavity with clinical and pathological features similar to pPNET; these include olfactory neuroblastoma, neuroendocrine carcinomas, undifferentiated carcinomas, lymphomas, and amelanotic melanoma (SHAH; PEREZ-ORDÓÑEZ, 2016). Microscopically, an olfactory neuroblastoma is characterized by the proliferation of columnar cells with rosettes formation being more frequently observed relative to PNETs (DUNGWORTH et al., 1999). Immunohistochemical analysis shows that cytokeratin expression is the main characteristic of neuroendocrine carcinomas (SHAH; PEREZORDÓÑEZ, 2016). The absence of expression for cytokeratin, CD3 and CD79 acy in this case excludes the diagnosis of both carcinomas and lymphomas. The present study concludes that pPNET should be included in the differential diagnosis of proliferative lesions and obstructions of the nasal cavity of heifer, and ultimately confirmed by histopathology and immunohistochemical evaluation.

\section{References}

BERROCAL, A.; MONTGOMERY, D. L.; MACKIE, J. T.; STORTS, R. W. Primitive neuroectodermal tumor in the spinal cord of a Brahman crossbred calf. Veterinary Pathology, Washington, v. 42, n. 6, p. 834-836, 2005.

DUNGWORTH, D. L.; HAUSER, B.; HAHN, F. F.; WILSON, D. W.; HAENICHEN, T.; HARKEMA, J. R. Tumors of the nasal and paranasal regions. In: SCHULMAN, Y. WHO international histological classification of tumors of the respiratory system of domestic animals. $2^{\text {th }}$ ed. Washington: Armed Forces Institute of Pathology, 1999. v. 6, p. 20-21.

KATAYAMA, K. I.; KUROKI, K.; UCHIDA, K.; NAKAYAMA, H.; SAKAI, M.; NISHIMURA, R.; SASAKI, N.; DOI, K. A case of canine primitive neuroectodermal tumor (PNET). Journal of Veterinary Medical Science, Tokyo, v. 63, n. 1, p. 103-105, 2001.

KOESTNER, A.; BILZER, T.; FATZER, R.; SCHULMAN, F. Y.; SUMMERS, B. A.; VAN WINKLE, T. J. Tumors of neuroepithelial tissue. In: SCHULMAN, Y. WHO histological classification of tumors of the nervous system of domestic animals. $2^{\text {th }}$ ed. Washington: Armed Forces Institute of Pathology, 1999. v. 5, p. 25.

LUCAS, M. N.; NGUYEN, F.; ABADIE, J.; KANE, Y.; CUILLIERE, P.; WYERS, M. Cerebral primitive neuroectodermal tumour in a heifer. Journal of Comparative Pathology, Edinburgh, v. 128, n. 2-3, p. 195-198, 2003. 
SHAH, K.; PEREZ-ORDÓÑEZ, B. Neuroendocrine neoplasms of the sinonasal tract: neuroendocrine carcinomas and olfactory neuroblastoma. Head and Neck Pathology, New York, v. 10, n. 1, p. 85-94, 2016.

UCHIDA, K.; MURAKAMI, T.; TOMETSUKA, T.; IWAKIRI, A.; YAMAGUCHI, R.; TATEYAMA, S. Peripheral neuroblastoma and primitive neuroectodermal tumor in Japanese black cattle. Journal of Veterinary Medical Science, Tokyo, v. 60, n. 7, p. 871-875, 1998.
WILSON, D. W.; DUNGWORTH, D. L. Tumors of the respiratory tract. In: MEUTEN, D. J. Tumors in domestic animals. $4^{\text {th }}$ ed. Ames: Iowa State Press, 2002. p. 371372.

WINDFUHR, J. P. Primitive neuroectodermal tumor of the head and neck: incidence, diagnosis, and management. Annals of Otology, Rhinology \& Laryngology, Saint Louis, v. 113, n. 7, p. 533-543, 2004. 